\title{
Letter to the editor: Effective treatment of locally advanced periocular basal cell carcinoma with oral hedgehog pathway inhibitor
}

\author{
Nilay Yuksel ${ }^{1}$ (iD \\ Received: 20 June 2021 / Revised: 20 June 2021 / Accepted: 2 July 2021 / Published online: 22 July 2021 \\ (c) The Author(s), under exclusive licence to Springer-Verlag GmbH Germany, part of Springer Nature 2021
}

\section{Dear Editor,}

I read with great interest the publication by Hou et al. entitled "Effective treatment of locally advanced periocular basal cell carcinoma with oral hedgehog pathway inhibitor" [1].

Since the targeted therapy for periocular and orbital tumors is becoming an exploding topic for ophthalmologists, we are getting familiar with every detail of these new drugs.

The authors have addressed immune checkpoint inhibitors as alternative systemic treatment options; however, they included sonidegib in this group of drugs. Sonidegib is an oral hedgehog pathway inhibitor (HPI), which has a different action mechanism from immune checkpoint inhibitors.

Surgical treatment of a locally advanced BCC would require orbital exenteration or surgery, resulting in defects that would be impossible to repair without loss of eye function or significant facial disfigurement. The HPIs are recommended for periocular locally advanced or metastatic basal cell carcinoma (BCC) to avoid exenteration [2].

In this case report, the information about orbital imaging or systemic evaluation of the patient is lacking. The authors stated the indication for sonidegib as the refusal of surgery by the patient. Since the patient eventually had an ectropion surgery after sonidegib treatment, both the tumor and ectropion surgery could be done at the same time. Most patients under HPI treatment have at least one side effect; therefore, the clinician should consider the advantages of the surgery over these costly drugs.

\section{Declarations}

Conflict of interest The author declares no competing interests.

\section{References}

1. Hou X, Rokohl AC, Ortmann M, Heindl LM (2020) Effective treatment of locally advanced periocular basal cell carcinoma with oral hedgehog pathway inhibitor? Graefes Arch Clin Exp Ophthalmol 258:2335-2337. https://doi.org/10.1007/s00417-020-04779-5

2. Sagiv O, Ding S, Ferrarotto R, Glisson B, Altan M, Johnson F, Elamin Y, Thakar SD, Nagarajan P, Esmaeli B (2019) Impact of Food and Drug Administration approval of vismodegib on prevalence of orbital exenteration as a necessary surgical treatment for locally advanced periocular basal cell carcinoma. Ophthalmic Plast Reconstr Surg 35:350-353. https://doi.org/10.1097/IOP. 0000000000001251

Publisher's note Springer Nature remains neutral with regard to jurisdictional claims in published maps and institutional affiliations.
Nilay Yuksel

ozturk.nilay@gmail.com

1 Ophthalmology Department, Ophthalmic Plastic Surgery

Service, Ankara City Hospital, Ankara, Turkey 